University of South Florida

DIGITAL COMMONS

Digital Commons @ University of

@ UNIVERSITY OF SOUTH FLORIDA

South Florida

Teaching and Learning Faculty Publications

Teaching and Learning

4-2019

\title{
Research with Children: Context, Power, and Representation
}

Danielle Lane

University of South Florida, dvanwie@mail.usf.edu

Jolyn Blank

University of South Florida, jblank@usf.edu

Phyllis Jones

University of South Florida, pjones7@usf.edu

Follow this and additional works at: https://digitalcommons.usf.edu/tal_facpub

\section{Scholar Commons Citation}

Lane, Danielle; Blank, Jolyn; and Jones, Phyllis, "Research with Children: Context, Power, and Representation" (2019). Teaching and Learning Faculty Publications. 85.

https://digitalcommons.usf.edu/tal_facpub/85

This Article is brought to you for free and open access by the Teaching and Learning at Digital Commons @ University of South Florida. It has been accepted for inclusion in Teaching and Learning Faculty Publications by an authorized administrator of Digital Commons @ University of South Florida. For more information, please contact digitalcommons@usf.edu. 


\section{The Qualitative Report}

Volume 24 | Number 4

How To Article 4

4-1-2019

\section{Research with Children: Context, Power, and Representation}

Danielle Lane

University of South Florida, dvanwie@mail.usf.edu

Jolyn Blank

University of South Florida

Phyllis Jones

University of South Florida

Follow this and additional works at: https://nsuworks.nova.edu/tqr

Part of the Early Childhood Education Commons

\section{Recommended APA Citation}

Lane, D., Blank, J., \& Jones, P. (2019). Research with Children: Context, Power, and Representation. The Qualitative Report, 24(4), 693-704. Retrieved from https://nsuworks.nova.edu/tqr/vol24/iss4/4

This How To Article is brought to you for free and open access by the The Qualitative Report at NSUWorks. It has been accepted for inclusion in The Qualitative Report by an authorized administrator of NSUWorks. For more information, please contact nsuworks@nova.edu. 


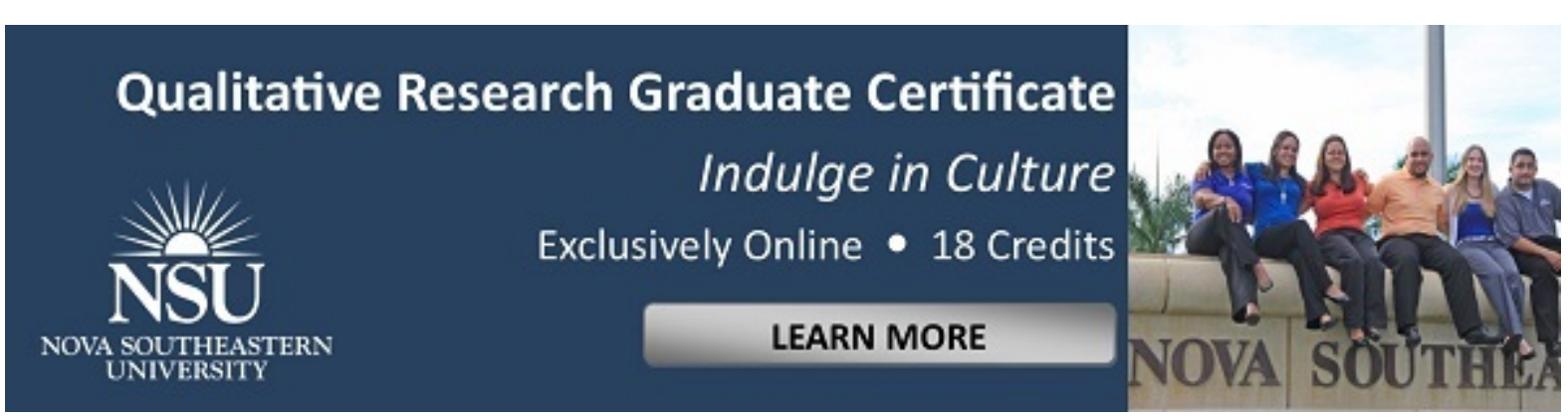

\section{Research with Children: Context, Power, and Representation}

\section{Abstract}

In this article, we examine methodological issues qualitative researchers encounter when they engage in research with children. Within this view, qualitative research is employed with children but not on children and focus is placed upon children's voices, agency, and the ways they participate with researchers in the research process (Einarsdóttir, 2007). Our discussion draws upon a study we conducted with four- and fiveyear-old children on the preschool playground. We reflect upon methodological issues pertaining to researching with children; issues of context, power, and representation.

\section{Keywords}

Research with Children, Power, Representation, Photo Elicitation, Mosaic Approach

\section{Creative Commons License}

\section{(c) (1)(2)}

This work is licensed under a Creative Commons Attribution-Noncommercial-Share Alike 4.0 License. 


\title{
Research with Children: Context, Power, and Representation
}

\author{
Danielle Lane, Jolyn Blank, and Phyllis Jones \\ University of South Florida, Tampa, Florida, USA
}

\begin{abstract}
In this article, we examine methodological issues qualitative researchers encounter when they engage in research with children. Within this view, qualitative research is employed with children but not on children and focus is placed upon children's voices, agency, and the ways they participate with researchers in the research process (Einarsdottir, 2007). Our discussion draws upon a study we conducted with four- and five-year-old children on the preschool playground. We reflect upon methodological issues pertaining to researching with children; issues of context, power, and representation. Keywords: Research with Children, Power, Representation, Photo Elicitation, Mosaic Approach
\end{abstract}

A growing body of literature addresses methods for involving young children in the research process (Palaiologou, 2014). Much of this research attempts to gain understanding of children's everyday lives from their perspectives, considering what is important for them in their daily experiences in home, school, and community contexts (Mason \& Danby, 2011). Research with children reflects a shift from viewing children as an object of study toward involving them in the research process and seeing them as actors whose voices are valued. (Einarsdóttir, 2007).

International interest in concepts related to the "paradigm of children's participation in research" has been fueled in part by Article 12 of the 1989 United Nations Convention on the Rights of the Child (Palaiologou, 2014). This document assumes that children are in need of protection and care "by reason of mental and physical immaturity" (p. 589) and that when deemed capable to express views, that the child be assured the right to express those views on matters affecting the child. This concept of "child voice" initially resonated so strongly with researchers that criticism was muffled (Lewis, 2010). As a result, along with the surge of scholarship related to methods of "co-researching" with children, a parallel strand of scholarship that problematizes children's participation in research is emerging. The parallel strand of scholarship aims to ensure the "implementation of children's right to participate and to make a positive change towards fighting adult centrism and challenging adults' status quo" (Shamrova \& Cummings, 2017, p. 400). Despite recent attention to "co-researching" with children and the implementation of participatory approaches to involving children in research, "the method should not be considered unproblematic" (Waller \& Bittou, 2011, p. 5).

In this article, we examine methodological issues qualitative researchers encounter when they engage in research with children. Our discussion draws upon a study we conducted with four- and five-year-old children. In the course of designing and conducting the study, we found ourselves frequently engaging in dialogue about what it means to engage in research with children rather than on children. We wondered to what extent children were engaged with us in the research process and whether or not we could or should represent their voices. Following a brief overview of the study to contextualize the discussion, we reflect upon issues pertaining to observation as surveillance, power, and representation. We argue that researchers should carefully reflect on the language they use to talk about research with children and the processes they use to construct representations of children in research. Further, we present a critical view of conducting research with children. We address issues related to participant observation and surveillance, relational power dynamics, and producing children's voices. 


\section{The Study}

The purpose of the study that serves to contextualize our consideration of methodological issues was to explore the broad concept of outdoor play that occurs on a particular preschool playground. We entered into this collaborative study with a shared interest in understanding how inclusion and exclusion functioned in child-initiated play groups. Danielle, the first author, is a former preschool teacher whose research has focused on inclusive practices in school settings. Jolyn, the second author, is also a former teacher of young children (pre-K through first grade). Phyllis, the third author is a previous assistant principal of a school that included a Pre-K program in England. She contributes her experiences researching with children using photo elicitation. While Danielle and Phyllis bring focus on Special Education, in her work in the field of Early Childhood Education, Jolyn has explored the multiple ways in which children communicate in the context of play, inquiry, and arts experiences. All members bring a qualitative research frame of reference to this study. Danielle, Jolyn, and Phyllis conducted this study while employed at a university in South Florida.

Together we aimed to understand more about the meanings children gave to their situated play experiences, how they developed group affiliations and social networks, the ways in which various roles were developed within peer groups, and how inclusion and exclusion functioned in peer play groups. A group of 24 children ages four- and five-year-old (one preschool classroom) participated in the study. We intended to include the children themselves in order to deepen understanding of the social and cultural issues that emerged as the children navigated their playground interactions (Ghafouri \& Wien, 2005). Ethical considerations of assent and photo use in researching with young children were addressed through the Institutional Review Board process. Parental consent was provided for all children included in the study and assent provided by children each time we collected data. Further, photos were only used in discussing play with children and will not be used in publication to ensure student confidentiality and protection.

We conducted weekly observations on the playground during the typically scheduled outdoor play time over a period of three months. We began our observations by individually surveying the playground then we selected a single play event we, as a team, would focus on for the remainder of our observation. We balanced constructing field notes and taking photographs during the observation and participating in child-initiated play scenarios when invited.

We also conducted individual and group interviews, employing photo elicitation strategies in which digital photographs of children engaged in play on the playground were used while conversing with children. Finally, we had a discussion with children who had emerged as leaders, or were part of a particular play event, about "who was in charge?" During these conversations, we employed a photo board with head shot photographs of the children.

Much of the scholarship pertaining to research with children has focused upon methods of interviewing young children. The use of photos as a method to capture the perspectives of young children has been suggested as a positive response to the three central challenges of researching the views of young children: developmentally appropriateness, power differentials between adults and children, and language barriers (Pyle, 2013). However, the way that photos have been incorporated in data collection with young children in has varied. This process of incorporating photographs in research with/on young children can be viewed as a continuum. The use of unfamiliar photographs in interviews lies at an early point in the continuum, progressing through to photo voice; children take their own photos and talk about images of their own choosing in interviews. An example of the former was in the design of a picture booklet intended to capture young children's views of inclusion in the North East of England (Jones, 2005). Here, children were invited to talk about images that conveyed ideas of "having 
fun," "learning together," and "joining in." This approach, often referred to as photo elicitation, has been adopted in other early years research (Yan, Yuejuan, \& Hongefen, 2005), but there have been concerns that the use of unfamiliar and impersonal photographs may have led to the potential of the children being, " disconnected from the process, limiting their investment and, in turn, the quality of the data" (Pyle, 2013, p. 1550). The inclusion of photographs of the actual children (Whitehurst \& Howell, 2006) involved in an inclusion project led to increased signs of motivation and participation of the young children in a subsequent project by Jones and Gillies (2010) exploring children's views of inclusion. Smith, Duncan, and Marshall (2005) also adopted this method in a similar project exploring the views of young children, however, there are lingering concerns about adult produced photographs (Pyle, 2013). At the other end of the continuum to photo elicitation, is a process where children take photographs and talk about those photographs as a way to talk about life experiences, sometimes referred to as photo voice (Drew, Duncan, \& Sawyer, 2010; Einarsdóttir, 2005). It has been shown that increased ownership of the research by children can be gained through photo voice methods in which children have some level of control over data collection (Meo, 2010).

The Mosaic approach combines the use of the photographs with other research methods and was developed in England in 2001 by Clark and Moss (2001) and is evident in more contemporary childhood research methods (Pyle, 2013). Central to the Mosaic approach is the use of interviews, observations, and photographs, which combine to contribute a multi-modal approach research method. The concerns of Nutbrown (2010), who warns that the use of photographs of children in research may represent a further "crisis of representation" and is an example of the "Othering" (rather than empowering) of young children in research, may be somewhat alleviated in the Mosaic approach. The Mosaic approach most accurately reflects the current project. The difference lays with the use of an iPad. In our later visits to the playground, we presented printed photographs on a photo board to further explore the children's ideas of leaders. Photo boards have been employed as an instructional strategy but not a research tool.

Researchers who focus on understanding children's lives and perspectives face multiple methodological issues. We argue that many of these issues echo those all qualitative researchers confront in their work; however, greater understanding of the particular nuances and ways research with children embodies these issues is needed.

\section{Participant Observation and Surveillance}

We embraced the work of Farrell, Kagan, and Tisdall, (2016) in our acknowledgement of the value of research in naturalistic settings. We were aware that we were committed to exploring new approaches and researching with the children, but we were using the traditional research tool of observation. This presented us a, as researchers, a problematic predicament. We wanted to catch natural episodes of the children's play, but we consistently struggled with the feelings of intrusion.

The playground was frenetic and very busy, the value of three researchers having a slightly different lens of the same event was particularly helpful in the hustle and bustle of the children's play. This is represented in an entry by Danielle in the collaborative research notes taken after the playground visits:

The approach of selecting play experiences as a group proved to be an effective method to gain the most insight into an event. I felt that as a group of researchers we were each able to pull in different aspects of an event. For example, I captured the events in photos while Jolyn was part of the play and Phyllis provided additional verbiage. 
We were committed to an ethical and natural approach that minimized intrusion in the children's play, but this is where we experienced tension. We often felt like intruders, as exemplified by a comment by Phyllis in the collaborative research notes, during the second field visit reflecting on entering the playground after the children were playing:

Today's visit left me feeling that my presence was intrusive in the children's play. The children had already gone out to play by the time we went onto the playground, unlike the first visit when we were present in the playground when the children moved into the playground. Did this make a difference?

This intrusive nature of our field work, in the children's natural environment, is echoed by Jolyn:

The idea of surveillance is really compelling to me as one to pursue both in terms of understanding the playground life and in terms of methodology. We are certainly intruding on something that is really theirs. This suggests there is a "child culture" happening on the playground, that it's not always apparent to teachers.

However, as noted by Phyllis after the fourth visit, the idea of intruder improved the more often we visited:

I felt a little more comfortable, taking a spot in playground and sitting there. Jolyn and Danielle did the same and I noticed natural interactions happening. When approached by Celeste, I was pulled into their hyena and oven game, but she showed no interest at looking at photos that I invited her to look at. It seemed to me that my involvement was very much on her terms, she was in charge!

It was clear that the children were aware of our presence on the playground. For example, Jolyn noted:

I observed that Darren told his playmates [who were engaged in a chasing game] to be quiet because we were not really teachers. This made me think of play the children are willing to share and play that they are not willing to share with adults/visitors.

So, even though we felt that our role as intruders changed as the weeks went by, the dilemma of "observing" the children was continuously problematic. In addition to our concerns of intruding upon the natural play occurring on the playground, the use of iPads also proved trying. Using the iPad to share digital photographs of the children's play, we engaged children in conversations of play events we had seen on the previous visit to the playground. The iPad itself provided a challenge to the researchers in the naturalistic environment. Danielle commented:

During today's discussions (with the children) we presented the photos on the iPad, which had the benefit of students being able to manipulate the device. On the other hand, the technology appeared to be a distraction for some of our students. 
The time lapse between the initial visit, when the photographs were taken, and when they were presented to children also proved potentially problematic, as noted by Danielle:

I began thinking about the delay in discussing play events with students. Would it be more beneficial to discuss the play event with students as they are happening? Does the setting impact student's willingness to discuss the photos?

It appears that every visit to the playground brought up methodological issues, which supports the idea that any research with children in the naturalistic setting, as opposed to, on children is complex and inherently challenging.

\section{Relational Power Dynamics}

Surface level considerations in involving young children in the research process center on beneficence. Palaiologou (2014) urges researchers to move toward considering not only the risk to the young child, but also how relationships between children and researchers are built and negotiated. In understanding the relationships between young children and a research team, the question of relational power dynamics arises. We ponder the notion that children may be more vulnerable in interactions with adults resulting in unequal power dynamics.

Research with children assumes a rapport between researcher and child or children; however, this assumption has been critiqued. Some scholars question the authenticity of these relationships and question the possibility of conducting research with participants in any situation where power relationships exist (Rengel, 2014). Perceptions of the researcher as an authority figure and the desire to please the researcher, in fear of a negative reaction, also contributes to the complexity of understanding the relationship between young children and researchers (Einarsdóttir, 2007). Further, researchers may impose their own perspectives and understandings onto children (Rengel, 2014).

Our experiences on the playground brought the challenges with relational power dynamics, highlighted in the literature, to life. Danielle, in a reflection of the day's data collection, wrote:

The research team entered the classroom early while students were finishing their free choice time. We attempted to talk to Celeste about photos we had taken on our previous visit; however, she was engrossed in her play and refused to participate in a discussion. As I joined the students on the playground I noticed Celeste drawing with chalk with a friend. I approached her, crouched down to her level and asked if she would look at some pictures I took last week. She swiftly denied my request. I asked her if she would be willing to share her photos with her friend and tell her all about them. She agreed and started dictating to her friend what was going on in the pictures, who was there and answering any questions I posed, but only as long as she was speaking to her friend. Celeste; however, made it very clear that I was not in charge, in this play event, and that things were going to be done her way.

As a team, we worked to employ a naturalistic approach in order to facilitate data collection that attempted to address potential unequal power dynamics. Aforementioned, observations and discussions with students took place during recess time on the playground. Play group sizes increased and decreased sporadically as we embraced students coming and going as they desired throughout the process. In the initial observations, questions of unequal power dynamics surfaced as students would tell each other to run away from where the research team 
stood or to avoid talking to us. Phyllis' reflection stated, "Billy is not interested in talking with us, and appears to actively instruct other children to be quiet around us!"

Phyllis, in our collaborative reflections, reported, "Danielle has established a rapport with Celeste - we will build on this." Danielle stated,

Walking away from today's visit I feel like we, as a team, are beginning to find ways into the student's play without compromising their creativity or stifling their growth through play. I have effectively built a relationship with Celeste, one of the main leaders, which has allowed me to begin gaining insight into the deeper relationships and nuances on the playground.

Environmental contexts and rapport with students (Rengel, 2014) are elements to consider in increasing authenticity and the reduction, not elimination, of unequal power dynamics. As observations continued, we became active participants in play episodes. For example, Darren's teacher, and some of his peers, indicated to us that he was often a leader during the outdoor play. He initiated a well-received zombie play scenario, but Darren was reluctant to talk with us directly about his Zombie play. Over time, he did invite Jolyn to co-play a modified version of zombies that involved ghosts. More than our attempts at conducting interviews or photoelicitation with children, the "participant status" of Jolyn's co-play seemed to lead to more authentic communication with Darren. Research pertaining to the adult's role in play with children would support this, suggesting that the adult's role as co-player is one of the few occasions when it is possible that the adult shares "power with" the child (Jones \& Reynolds, 2011). Other researchers cite this as potential evidence of "research with rather than on" children, but we remain skeptical. Further exploration of authentic co-play as a methodological approach to address power dynamics when researching with children is needed to address skepticism that remains.

\section{Representing Children's Voices}

The concept of representing children's voices as a way to recognize their perspectives has resonated strongly with researchers who engage in research with children. We wondered about our roles in producing child voice in the playground study and considered the ways in which relying on the idea of "giving voice to" may actually mask power differentials rather than empower children. One of the ways representing children's voices as an aim of research is problematic is because it implies that it is possible to "grasp voice and represent its essence" (Spyrou, 2011, p. 152). Another way representing children's voices is problematic is that it relies upon the maintenance of the research relationship as comprised of one person with power (the researcher) giving voice to the research subject (Pillow, 2003). This positions researchers as generous, and the researched as beneficiaries of their "gesture of humility" (p. 185). Although well-meaning, the preoccupation with representing children's voices operates from a construction of childhood that has "placed a group of people in the position in which others always speak for them" (Cannella, 1997, p. 44).

Much of the literature pertaining to research with children "has concerned itself with the problems associated with accessing children and/or their voice" in terms of refining observation, and more frequently, interviewing techniques adapted for children (Spyrou, 2011, p. 152). This focus on building a better interview or refining observation procedures is problematic because, while it is valuable to consider how to gain insight from children about their worlds, methods of doing research with children frequently seem to revert to reflect perspectives on the nature of knowledge as something to be "found" by researchers and conveyed accurately; portrayed as truth. We can "get" children's perspectives. Brinkmann and 
Kvale (2015) use a miner metaphor to illustrate this idea of knowledge collection. In the miner metaphor, knowledge is buried metal waiting to be unearthed - uncontaminated--by the miner. In contrast to this view on the nature of knowledge, qualitative researchers often claim to construct meaning in dialogue with children. This depends not on perfecting the tools and procedures utilized to capture children's voices, but rather on a commitment to carefully listening to children and paying attention to the nature of the relationships being formed.

Qualitative researchers generally acknowledge "data" as something they construct rather than as something they find. Observation and interview methods, for example, are ultimately processes of constructing descriptive accounts. Interpretations and representations of children's (or anyone else's) voices are always constructed by the researcher. According to Emerson, Fretz, and Shaw (2011), "Writing descriptive accounts of experiences and observation is not simply a process of accurately capturing as closely as possible observed reality, of 'putting into words' overheard talk and witnessed activities" (p. 5). Instead, field notes are the result of a researcher's transformation of observed events into words. They always present or frame observations in particular ways that reflect the view of the observer. Field notes from observation are, in essence, "The particular practice of representing the social reality of others through the analysis of one's own experience in the world of these others" (p. 14). These notions hold whether one is engaging in research with children or with adults. As an example, the following excerpt illustrates the way Jolyn transformed an observed event into words:

It's 11:26 a.m. (four-year-old) Darren informs two boys, "Now you're a person and you're a person." Darren raises his arms and roars. The people run, also roaring, as Darren chases. Then they pause for a moment, looking to Darren who breaks the play frame and orchestrates: "OK, you're the person, he's a person, and you run away." The response is immediate. More running and roaring. "I'm a monster!" a boy shouts, refusing to play a person. "You better run!" he forewarns, shouting "Rahhh!" and raising his arms menacingly to mark the transition.

Reflecting on this observation, Jolyn noted that Darren operated both within the play scenario and stepped outside of the play to position himself as the director (e.g., "OK, you're the person"). She noted:

I continued to wonder about Darren today and the observation strengthened my sense of him as a leader. Today I heard him give very direct commands, and saw others follow his directives. I also heard commentary from others that indicated his leadership is recognized (e.g., if Darren doesn't want to play monsters, we are not playing monsters today).

When Jolyn asked Darren his perspectives on who was directing the monster play, he indicated one of his peers was in charge. Another child, Ryan, initially self-identified as leader but quickly changed his mind and suggested Darren was in charge. A third preschooler, Amaya, commented, "Everyone is in charge. No one should fight." Jolyn constructed the monster play as a story about leadership in play and saw it as an opportunity to think about the ways the children themselves viewed group dynamics on the playground. In this way, the voice represented was as much hers as the children's.

The notion of childhood itself is a construction. Childhood as a distinct phase of human life is derived from a Western idea that human beings develop in a linear fashion (Canella, 1997). Twentieth century developmentalists sought to portray a universal child who progresses 
through predictable stages, attending "to those aspects of development that can be explained in terms of biology and/or evolution" (Walsh, 2002, p. 102). In contrast, postmodern ideas about children and childhood reject notions of childhood as moving though stages, privileging instead concepts of difference, particularity, and irregularity. This awareness led researchers to challenge dominant grand narratives and practices that situate the researched Other, in this case child, as a "passive, reified, less intelligent being" (Canella \& Lincoln, 2007, p. 320).

The focus on representing children's voices reflects conflicting constructions of children that work to serve researchers in various ways. Most often, research with children operates from an explicitly stated assumption that children are "strong, capable, and knowledgeable experts on their own lives" (Einarsdóttir, 2007, p. 199). First, we note that this doesn't suggest that children are "co-researchers," but rather that they are "reliable informants and give valuable and useful information" (p. 199). Second, we note the contradiction between this idea and the United Nations' (1989) Convention on the Rights of the Child's assumption (drawn from the 1959 Declaration of the Rights of the Child) that children are in need of protection and care "by reason of mental and physical immaturity," and that when deemed capable to express views that the child be assured the right to express those views on matters affecting the child. Defining children as "intellectually lacking and/or possessing inarticulate voices ultimately reinforces the language of those in power" (Canella \& Lincoln, 2007, p. 320).

The concern with giving children voice to better understand their experiences arose from a sense of children as silenced, disempowered, and in need of representation (Spyrou, 2011). Yet the construction of children as either capable/active or needy/passive appear simultaneously in the discourses of research with children. This illuminates the ways in which the desire to position children as actors who engage with researchers rather than as objects of research creates an "illusion of participation" that benefits researchers (Palaiologou, 2014, p. 690). Spyrou (2011) provided a critique of the preoccupation with representing children's voices in child-centered research by exploring their limits and problematizing their use in research. He argued:

Critical, reflexive researchers need to reflect on the processes which produce children's voices in research, the power imbalances that shape them and the ideological contexts which inform their production and reception, or in other words issues of representation. At the same time, critical, reflective researchers need to move beyond claims of authenticity and account for the complexity behind children's voices by exploring their messy, multi-layered and nonnormative character. (p. 151)

The concept of representing children's voices as a way to recognize their perspectives has resonated strongly with those who engage in research with children. We acknowledge that the idea of research with children rather than on children is reflective of a genuine belief that it is liberatory and empowers children. Yet, without critique of the underlying assumptions at play in the complexities of researcher relationships, attempts to represent children's voices may actually reproduce power differentials in unintended ways. Masking researcher power is perhaps even more oppressive than an overt display of control and surveillance. Rather than seeking better methods of accessing voice and better means of representation, we acknowledge the call to represent children's voices while continuing to challenge the representations we create as theirs or as "true." 


\section{Discussion}

In this article, we examined issues pertaining to research with children and considered them in relation to our own research experiences with young children. Throughout our methodological reflections, we complicated issues of participant observation and surveillance, relational power dynamics, and producing children's voices. In doing so, we problematized the notion of doing research with children. Beyond devising unique methods of doing research with children, we argue that it is also important to reflect on the processes that produce children's voices in research. This brings to mind Pillow's (2003) reflexivities of discomfort, and the following questions she poses:

- Can we truly represent the voice of another? Should this even be our aim?

- How does the strategy of making evident how the Other has participated in making his/her own image in the research serve to mask power rather than distribute it?

- Whose story is it?

One of the ways reflexivity in research with children has been enacted is to attempt to show how children have participated in making his or her own story or image in the research, to "give voice" to children by placing emphasis on their words, and to consider ways children can help develop the research project. In contrast, Pillow's (2003) reflexivities of discomfort provide insight into how researchers produce stories, images, and ideas. In the end, we reflect-as in all qualitative research - that the stories we construct and tell are ultimately more ours than theirs.

Contemporary conceptualizations of childhood as socially constructed and situated in experience make it possible to see children as capable, active participants in the determination of their own lives. These considerations imply a shift in conceptualizing research with children, framing its issues as similar to those encountered when engaging in qualitative research with adults. However, terms like "participatory" and "co-researcher" used in describing research with children are problematic because they have masked contextual and relational issues of power dynamics, observation, and representation of student voice that are well-established in the larger arena of qualitative research methodologies.

\section{References}

Brinkmann, S., \& Kvale, S. (2015). Interviews: Learning the craft of qualitative research interviewing. Los Angeles, CA: Sage.

Canella, G. S. (1997). Deconstructing early childhood education: Social Justice \& Revolution. New York, NY: Peter Lang.

Canella, G. S., \& Lincoln, Y. S. (2007). Predatory vs. dialogic ethics: Constructing an illusion or ethical practice as the core of research. Qualitative Inquiry, 13(3), 315-336.

Clark, A., \& Moss, P. (2001). Listening to young children: The Mosaic approach. London, UK: National Children's Bureau for the Joseph Rowntree Foundation.

Drew, S., Duncan, R., \& Sawyer, S. (2010). Visual storytelling: A beneficial but challenging method for health research with young people. Qualitative Health Research, 20, 16771688. doi:10.1177/1049732310377455

Einarsdóttir, J. (2005). Playschool in pictures: Children's photographs as a research method. Early Child Development and Care, 175(6), 523-541. doi.org/10.1080/03004430500131320

Einarsdóttir, J. (2007). Research with children: Methodological and ethical challenges. 
European Early Childhood Education Research Journal, 15(2), 197-211. doi:10.1080/13502930701321477

Emerson, R. M., Fretz, R. I., \& Shaw, L. L. (2011). Writing ethnographic fieldnotes (2 ${ }^{\text {nd }}$ ed.). Chicago, IL: The University of Chicago Press.

Farrell, A., Kagan, S. L., \& Tisdall, E. M. (2016). The SAGE handbook of early childhood research. London, UK: SAGE Publications Ltd.

Ghafouri, F., \& Wien, C. A. (2005). 'Give us a privacy:' Play and social literacy in young children. Journal of Research in Childhood Education, 19(4), 279-291.

Jones, P. (2005). Inclusion: Lessons from the children. British Journal of Special Education, 32(2), 60-66.

Jones, P., \& Gillies, A. (2010). Engaging young children in research about an inclusion project. In R. Rose (Ed.), Confronting obstacles for inclusion-international responses to developing education (pp. 123-136). London, UK: Routledge College Press.

Jones, E., \& Reynolds, G. (2011). The play's the thing: Teachers' roles in children's play (2 ${ }^{\text {nd }}$ ed.). New York, NY: Teachers College Press.

Lewis, A. (2010). Silence in the context of child 'voice.' Children and Society, 24, 14-23.

Mason, J., \& Danby, S. (2011). Children as experts in their lives: Child inclusive research. Childhood Indicators Research, 4, 185-189. doi:10.1007/s12187-011-9108-4

Meo, A. I. (2010). Picturing students' habitus: The advantages and limitations of photoelicitation interviews in a qualitative study in the city of Buenos Aires. International Journal of Qualitative Methods, 9(2), 149-171.

Nutbrown, C. (2010). Naked by the pool? Blurring the image? Ethical issues in the portrayal of young children in arts-based educational research. Qualitative Inquiry, 17(1), 3-14. doi:10.1177/1077800410389437

Palaiologou, I. (2014). 'Do we hear what children want to say?' Ethical praxis when choosing research tools with children under five. Early Childhood Development and Care, 184(5), 689-705. doi:10.1080/03004430.2013.809341

Pillow, W. (2003). Confession, catharsis, or cure? Rethinking the uses of reflexivity as methodological power in qualitative research. International Journal of Qualitative Studies in Education, 16(2), 175-196. doi:10.1080/0951839032000060635

Pyle, A. (2013). Engaging young children in research through photo elicitation. Early Child Development and Care, 183(11), 1544-1558. doi:10.1080/03004430.2012.733944

Rengel, K. (2014). Research with children in kindergartens. Procedia - Social and Behavioral Sciences, 146, 34-39. doi:10.1016/j.sbspro.2014.08.083

Shamrova, D., \& Cummings, C. (2017). Participatory action research (PAR) with children and youth: An integrative review of methodology and PAR outcomes for participants, organizations, and communities. Children and Youth Services Review, 81, 400-412. doi:10.1016/j.childyouth.2017.08.022

Smith, A., Duncan, J., \& Marshall, K. (2005). Children's perspectives on their learning: Exploring methods. Early Child Development and Care, 175, 473-487. doi:10.1080/03004430500131270

Spyrou, S. (2011). The limits of children's voices: From authenticity to critical, reflexive representation. Childhood, 18(2). 151-165. doi: 10.1177/0907568210387834

United Nations. (1989). Convention on the rights of the child. Retrieved from http://www.ohchr.org/EN/ProfessionalInterest/Pages/CRC.aspx

Waller, T., \& Bitou, A. (2011). Research with children: Three challenges for participatory research in early childhood. European Early Childhood Education Research Journal, 19(1), 5-20. doi:10.1080/1350293X.2011.548964

Walsh, D. (2002). Constructing an artistic self: A cultural perspective. In L. Bresler \& C.M. Thompson (Eds.), The arts in children's lives: Context, culture, and curriculum (pp. 
101-112). Dordrecht, The Netherlands: Kluwer Academic Publishers.

Whitehurst, T., \& Howells, A. (2006). 'When something is different people fear it': Children's perceptions of an arts-based inclusion project. Support for Learning, 21, 40-44. doi:10.1111/j.1467-9604.2006.00399.x

Yan, L., Yuejuan, P., \& Hongfen, S. (2005). Comparative research on young children's perceptions of play - an approach to observing the effects of kindergarten educational reform. International Journal of Early Years Education, 13, 101-112. doi:10.1080/09669760500170982

\section{Author Note}

Danielle Lane is a doctoral candidate in Special Education at the University of South Florida. She is currently serving as a pre-doctoral fellow and instructor of education at Elon University in North Carolina. Her research focuses on global understandings of autism spectrum disorder in various cultural contexts. Specifically, she is interested in centralizing the importance of inclusive practices in educational provisions that are provided to students with autism spectrum disorder. Danielle teaches courses in Special Education at the undergraduate level and serves as a university supervisor for pre-service teacher candidates. She also serves as the editorial assistant for International Journal of Whole Schooling. Correspondence regarding this article can be addressed directly to: dvanwie@ mail.usf.edu.

Dr. Jolyn Blank is an Associate Professor of Early Childhood Education in the Department of Teaching \& Learning at the University of South Florida. Dr. Blank's research focuses on the relationship between teacher learning and school contexts and the educational potential of artistic and aesthetic experiences for young children. She investigates the ways arts and inquiry, integrated processes of investigating and representing meaning using multiple modes of communication, are enacted within the diverse social and ideological complexities of contemporary early schooling. Dr. Blank teaches courses in Early Childhood Education in the undergraduate teacher preparation program and at the master's and doctoral levels. Her courses focus on play and learning, the arts in early learning, and qualitative research. She also serves as the pedagogical advisor to the USF Preschool for Creative Learning, bringing together faculty, pre-service teachers, in-service teachers, and graduate students to engage in co-inquiry within the context of authentic classroom experiences. Dr. Blank served as Associate Editor of the International Journal of Education and the Arts and served on the editorial boards of Young Children, Early Childhood Research \& Practice, and The Qualitative Report.

Dr. Phyllis Jones is a professor in the department of Teaching \& Learning at the University of South Florida. Phyllis taught and was a deputy head in schools in the UK for fifteen years before she entered teacher education. She came to USF in 2003. She is author of Curricula for Students with Severe Disabilities: Narratives of Standards-Referenced Good Practice, Inclusion in the Early Years: Stories of good practice, co-author of Collaborate Smart and lead editor of "A Pig Don't Get Fatter the More You Weigh It": Balancing Assessment for the Classroom, Leading for Inclusion, Creating Meaningful Inquiry in the Inclusive Classroom, Pushing the Boundaries: Developing Inclusive Practices through Integration of Insider Perspectives, co-editor of The Routledge Companion to Severe, Profound and Multiple Learning Difficulties and The Foundations of Inclusive Education Research. She is co-editor of International Journal of Whole Schooling, sits of the editorial board of Disability \& Society and is a regular reviewer for British Journal of Special Education, Journal of Child and Family Studies, International Journal of Inclusive Education, Journal of Teacher Education and International Review of Education. Internationally, she has worked in England, Ireland, New Zealand, Thailand and Mexico. Phyllis has a current Fulbright application and has been 
successful at the USA country level, her application has been forwarded to New Zealand for this review.

Copyright 2019: Danielle Lane, Jolyn Blank, Phyllis Jones, and Nova Southeastern University.

\section{Article Citation}

Lane, D., Blank, J., \& Jones, P. (2019). Research with children: Context, power, and representation. The Qualitative Report, 24(4), 693-704. Retrieved from https://nsuworks.nova.edu/tqr/vol24/iss4/4 